\title{
Implementasi Alat Prediksi Curah Hujan Menggunakan Metode Embedded System di Kelurahan Wonokoyo Kecamatan Kedungkandang Kota Malang
}

\author{
Ida Wahyuni ${ }^{1}$, Philip Faster Eka Adipraja ${ }^{2}$, Sri AnggrainiKusuma Dewi ${ }^{3}$ \\ 1,2,3 Program Studi Informatika, STMIK ASIA, Malang \\ 1idawahyuni@asia.ac.id, ${ }^{2}$ philipfaster@gmail.com, ${ }^{3}$ kusumadewi2309@gmail.com
}

\begin{abstract}
ABSTRAK. Kelurahan Wonokoyo adalah salah satu kelurahan di Kota Malang yang kaya akan potensi pertanian. Banyak komoditi pertanian tebu dan palawija yang dihasilkan kelurahan Wonokoyo khususnya di RW 5 yang dihimpun oleh Kelompok Tani Ainul Hayat. Namun karena kondisi iklim yang tidak menentu membuat curah hujan menjadi sulit diprediksi. Padalah jumlah curah hujan sangat menentukan awal masa tanam dan masa pemupukan. Selama ini para petani hanya mengandalkan pengalaman dalam menentukan awal masa tanam dan masa pemupukan, namun karena curah hujan tidak menentu sering terjadi kesalahan dalam memperkirakan curah hujan. Kesalahan dalam memprediksi curah hujan mengakibatkan hasil panen dan kulitas pemupukan menjadi tidak optimal. Alat prediksi curah hujan sangat dibutuhkan untuk memperkirakan rata-rata curah hujan yang akan turun selama sepuluh hari ke depan. Dengan mengetahui perkiraan curah hujan, petani akan mempunyai pedoman dalam menentukan apakah sepuluh hari ke depan baik digunakan untuk awal masa tanam atau masa pemupukan. Alat prediksi curah hujan dibuat dengan sensor pencatat data cuaca dan software embedded system untuk memprediksi curah hujan. Metode yang akan digunakan yaitu hybrid FIS-GA yang pernah digunakan sebagai metode prediksi curah hujan. Hasil luaran yang ditampilkan oleh alat prediksi curah hujan adalah rata-rata curah hujan yang akan terjadi sepuluh hari ke depan.
\end{abstract}

Kata Kunci: Curah Hujan, Kota Malang, Pertanian, Prediksi Curah Hujan, Implementasi.

\begin{abstract}
Wonokoyo Village is one of the villages in Malang City which is rich in agricultural potential. Many sugarcane and palawija agricultural commodities are produced by Wonokoyo village, especially in RW 5 which are collected by Ainul Hayat Farmers Group. However, due to erratic climatic conditions, rainfall is difficult to predict. Even though the amount of rainfall really determines the beginning of the planting period and the period of fertilization. So far, farmers have only relied on experience in determining the beginning of the planting period and the period of fertilization, but because of erratic rainfall there is often an error in estimating rainfall. Errors in predicting rainfall cause yields and quality of fertilization to be not optimal. Rainfall prediction tools are needed to estimate the average rainfall that will drop over the next ten days. By knowing the estimated rainfall, farmers will have guidelines in determining whether the next ten days are good to be used for the beginning of the planting period or fertilization period. Rainfall prediction tools are made with weather data recording sensors and embedded system software to predict rainfall. The method that will be used is a hybrid FIS-GA which has been used as a method of predicting rainfall. The output results displayed by the rainfall prediction are the average rainfall that will occur in the next ten days.
\end{abstract}

Keyword:Rainfall, Malang City, Agriculture, Rainfall Prediction, Implementation.

\section{PENDAHULUAN}

Kota Malang merupakan salah satu kota besar di Provinsi Jawa Timur. Lokasi geografis Kota Malang yang terdiri dari daerah pegunungan dan perbukitan membuat kota ini mempunyai potensi pertanian yang sangat bagus. Banyak sekali komoditi pertanian yang dimiliki Kota Malang salah satunya adalah tanaman padi, berbagai jenis tanaman palawija, dan tebu (Ardianto, 2009). Melimpahnya potensi pertanian di Kota Malang menjadi salah satu potensi yang harus terus ditingkatkan.

Kelurahan Wonokoyo adalah salah satu kelurahan yang terletak di Kecamatan Kedungkandang, Kota Malang. Daerah Wonokoyo terletak di pinggiran kota dengan bentuk topologi desa berupa perbukitan yang masih asri. Disana banyak ditemui komoditi pertanian palawija dan tebu. Hampir setiap tiga bulan sekali selalu ada hasil panen palawija yang meliputi sayur mayur, rempah-rempah, ketela pohon, dan lain-lain. Bahkan tanaman tebu dari pertanian di Kelurahan Wonokoyo merupakan salah satu pemasok tebu terbanyak untuk dua pabrik gula di Kota 
Malang. Deaerah di Kelurahan Wonokoyo yang menghasilkan komoditi palawija dan tebu berada di RW 5 yang terdiri dari tiga RT yaitu RT 1, RT 2, dan RT 3. Para petani di RW 5 tersebut terkelompok ke dalam satu perhimpunan yaitu Kelompok Tani Ainul Hikmah yang diketuai oleh Bapak M. Sholeh. Gambaran dari area pedesaan di Kelurahan Wonokoyo RW 5 ditunjukkan pada Gambar 1 .
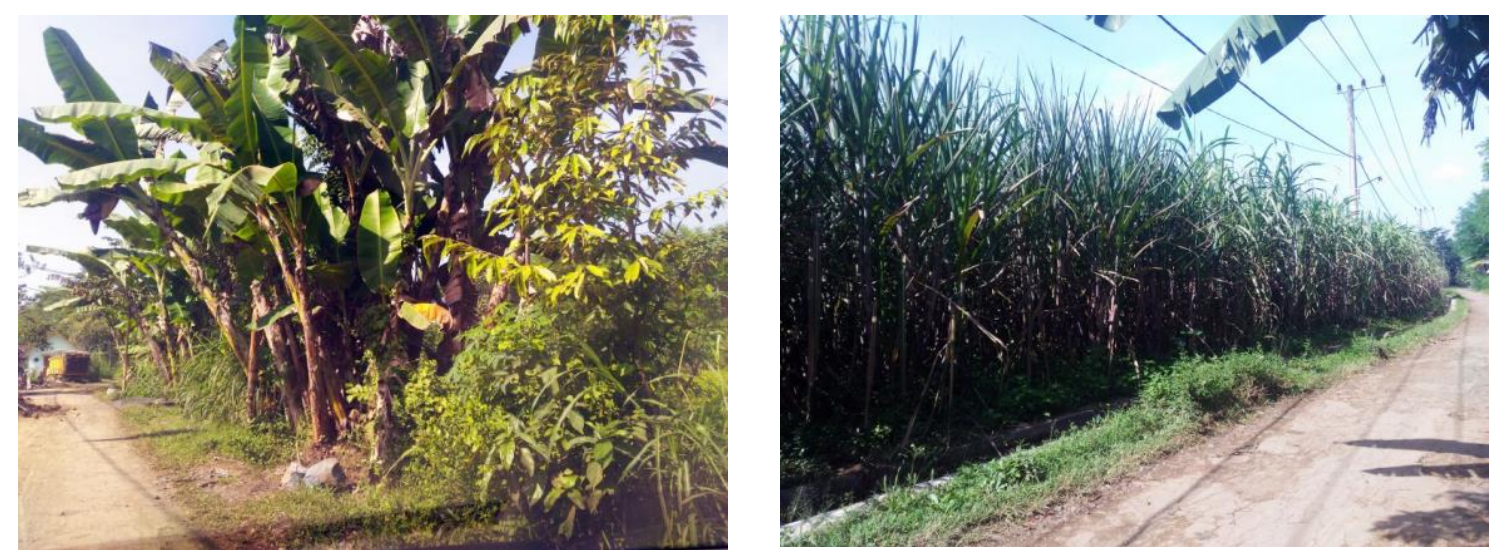

Gambar 1. Gambaran Area KelurahanWonokoyo RW 5

Kondisi ladang pertanian di KelurahanWonokoyo RW 5 merupakan jenis ladang tadah hujan, dimana mereka memanfaatkan curah hujan untuk memenuhi keperluan air untuk ladang mereka. Komoditi yang biasa ditanam di ladang adalah tanaman palawija seperti kacang panjang, kunyit, jahe, ketela pohon, dan jagung. Selain itu komoditi terbesar lainnya adalah tebu. Semua tanaman pertanian tersebut sangat tergantung dengan curah hujan mulai tahap penanaman sampai pemupukan (Asriasuri, 1998). Gambaran mengenai pertanian tebu dan pertanian palawija di KelurahanWonokoyo ditujukan pada Gambar 2.

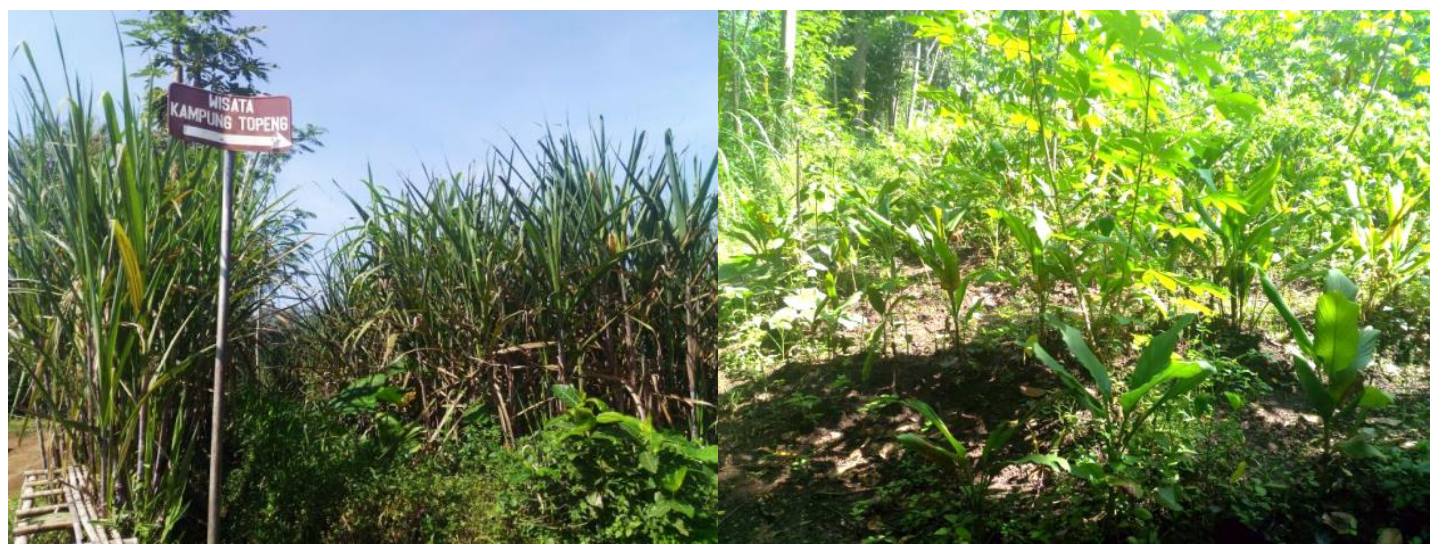

Gambar 2. Pertanian Tebu dan PertanianPalawija di Wonokoyo

Namun di saat terjadi perubahan iklim dunia sekitar tahun 2010, mengakibatkan curah hujan menjadi sangat sulit untuk diprediksi (Wahyuni, Mahmudy, \& Iryani, 2016). Hal tersebut mengakibatkan para petani sulit memperkirakan kapan awal masa tanam yang tepat agar mendapatkan curah hujan yang cukup. Selain itu, petani juga mengalami kesulitan dalam memprediksikan kapan memulai masa pemupukan, dimana masa pemupukan dilakukan saat curah hujan tidak terlalu banyak.

Pelaksanaan Program Kemitraan Masyarakat (PKM) yang berkerja sama dengan Kelurahan Wonokoyo dan Kelompok Tani Ainul Hayat di KelurahanWonokoyo RW 5 memberikan solusi dari permasalahan tersebut, khususnya solusi dalam memprediksi curah hujan. Solusi yang disepakati dengan kedua mitra meliputi: (1) Pembuatan alat prediksi curah hujan untuk 
memprediksi curah hujan di area KelurahanWonokoyo, (2) Pemasangan alat prediksi curah hujan di RW 5, Kelurahan Wonokoyo, (3) Pelatihan dan pendampingan penggunaan dan perawatan alat prediksi curah hujan, (4) Pelatihan dan pendampingan manajemen penentuan awal masa tanam dan masa pemupukan.

\section{METODE}

\section{Tahapan Pelaksanaan}

Untuk mengatasi masalah yang dihadapi para petani dalam menentukan perkiraan kondisi curah hujan ada beberapa tahapan yang akan dilakukan. Pertama dilakukan analisis masalah pada kelompok tani di KelurahanWonokoyo, sehinggadidapatkansebuah masalah yaitu petani kesulitan dalam memperkirakan jumlah curah hujan, sehingga kesulitan dalam menentukan awal masa tanam dan masa pemupukan. Setekah diketahui masalahnya, maka dibuat sebuah solusi bernama Alat Prediksi Curah Hujan (APCH). Setelah alat tersebut selesai dibuat, maka akan dilakukan pemasangan APCH di KelurahanWonokoyo. Setelah alat terpasang perlu dilakukan sosialisasi tentang cara penggunaan alat, cara membaca hasil, dan cara perawatan. Langkah terakhir adalah memberikan edukasi kepada petani bagaimana cara membaca hasil pengukuran cuaca dan hasil prediksi curah hujan untuk agar dapat digunakan sebagai pedoman dalam penentuan masa tanam dan masa pemupukan. Tahapan pelaksanaan secara singkat dapat dilihat pada Gambar 3.

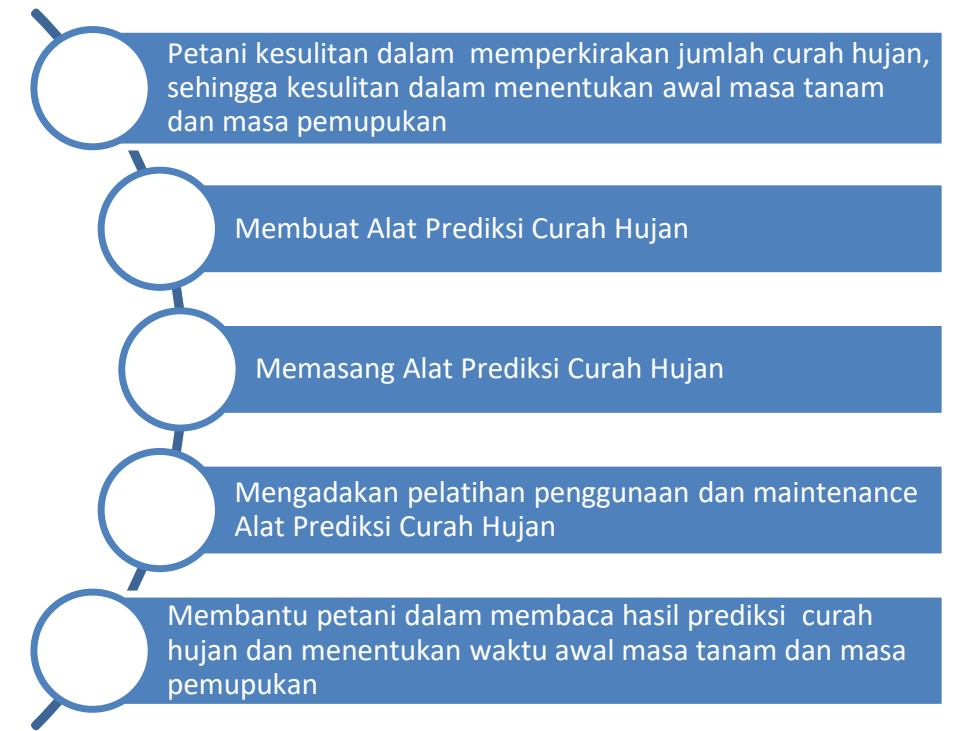

Gambar 3. Tahapan Pelaksanaan Program Pengabdian yang Diusulkan

\section{Perancangan Alat Prediksi Curah Hujan}

Perancangan Alat Prediksi Curah Hujan sudah dilakukan pada penelitian sebelumnya (Wahyuniet.al, 2017). Alat tersebut terdiri dari sensor cuaca yang dipasang di KelurahanWonokoyo RW 5 dansoftware prediksi curah hujan yang dijalankan oleh petugas BPBD Kota Malang. Petani dan masyarakat dapat melihat tampilan hasil pengukuran cuaca dan hasil prediksi pada website dan smartphone Android.

Alat Prediksi Curah Hujan dibuat dengan beberapa peralatan yaitu sensor cuaca, software prediksi menggunakan hybrid FIS-GA (Wahyuni \& Mahmudy, 2017). Sensor cuaca yang digunakan antara lain sensorwin vane, sensoranemometer, sensor pengukur hujan atau rain gauge, dan sensor wather link cuaca atau BHT4DV yang terdiri dari sensor tekanan atau bmp 180, sensor suhu dan kelembaban atau AM 2320. Sensorwin vane digunakan untuk menentukan arah angin. Sensoranemometer digunakan untuk menentukan kecepatan angin. Sensor rain gauge digunakan untuk mengukur curah hujan. Sensor bmp 180 digunakan untuk mengukur tekanan udara. Sensor suhu DHT 11 digunakan untuk mengukur suhu dan kelembaban. Gambar masing-masing komponen sensor cuaca dapat dilihat pada Gambar 4. 


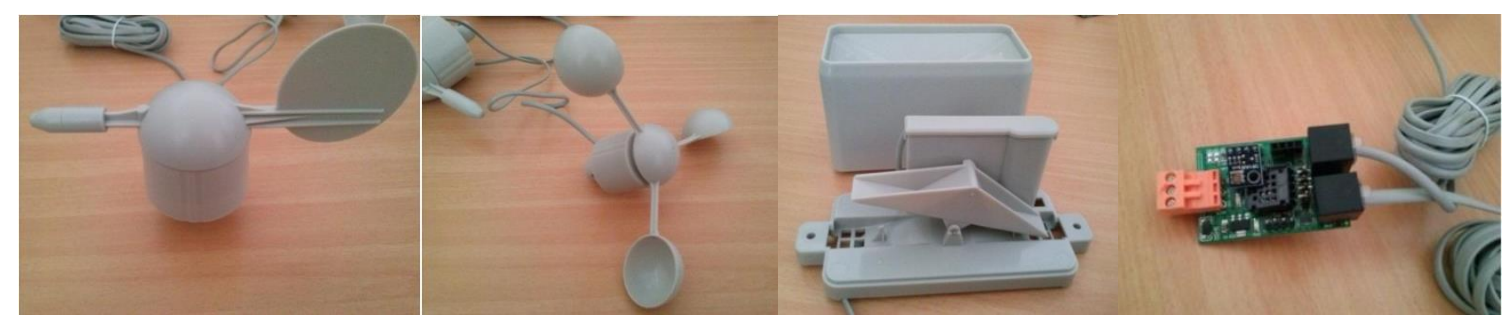

Gambar 4. (Kiri-Kanan) Wind Vane, Anemometer, Rain Gauge, Weather Link dengan Sensor Tekanan, Suhu, dan Kelembaban

\section{Pelaksanaan Pelatihan}

\section{A. Materi Penggunaan Alat Prediksi Curah Hujan}

Saat pelaksanaan pengabdian masyarakat dilakukan pelatihan sebagai tahap awal tatap muka dengan Badan Penanggulangan Bencana Daerah (BPBD) Kota Malang bagaimana cara penggunaan Alat Prediksi Curah Hujan. Diharapkan BPBD selaku pihak yang akan mengelola Alat Prediksi Curah Hujan mampu mengoperasikan alat dan software demi kemudahan dalam menentukan prediksi curah hujan.

\section{B. Materi Perawatan (Maintanance)}

Saat pelaksanaan pengabdian masyarakat dilakukan pelatihan tahap kedua tatap muka dengan Badan Penanggulangan Bencana Daerah (BPBD) Kota Malang dan para masyarakat kelompok usaha tani serta masyarakat umum terhadap bagaimana cara perawatan dan pemeliharaan Alat Prediksi Curah Hujan. Diharapkan pihak BPBD Kota Malang mampu memahami dan menangani permasalahan saat terjadi gangguan pada Alat Prediksi Curah Hujan demi kelancaraan penggunaan alat yang telah disediakan oleh pihak tim pengabdian masyarakat.

\section{Materi Penentuan Masa Tanam}

Saat pelaksanaan pengabdian masyarakat selain dilakukan pelatihan pembacaan hasil prediksi curah hujan, juga diajarkan cara penentuan awal masa tanam dan masa pemupukan yang baik berdasarkan hasil prediksi curah hujan. Diharapkan dengan pengetahuan tersebut Kelompok Tani Ainul Hayat tidak akan kesulitan lagi dalam menentukan masa tanam dan masa pemupukan.

\section{Pemateri}

Pelatihan diberikan oleh tim pemateri/pakar yang kompeten di bidang teknik informatika, sistem informasi, software dan elektronika dalam sebuah sistem, selain itu dibantu dengan anggota tim pengabdian masyarakat.

\section{E. Modul Pelatihan}

Setiap peserta anggota kelompok usaha akan diberikan sebuah modul pelatihan sebagai bahan pembelajaran awal sebelum pelatihan dilakukan yang terdiri dari:

1. Panduang penggunaan alat

2. Panduan perawatan dan pemeliharaan alat

3. Panduan manajemen data curah hujan

\section{F. Tempat dan Waktu Latihan}

Rencana pelaksanaan kegiatan dan waktu pelaksanaan kegiatan akan dilakukan sesuai dengan paparan berikut:

a. Ruang Rapat Badan Penanggulangan Bencana Daerah (BPBD) Kota Malang

b. Tempat di SND Wonokoyo II, RW 5, Kelurahan Wonokoyo, Kecamatan Kedungkandang, Kota Malang.

\section{HASIL DAN PEMBAHASAN}




\section{Pelaksanaan Pra Pengabdian}

Pelaksanaan Program Kemitraan Masyarakat (PKM) dimulai dengan persiapan instrumen pengabdian berupa pembelian peralatan sensor cuaca dari Amerika dan membeli dan membuat komponen elektronik Indonesia. Waktu yang dibutuhkan untuk persiapan instrumen kurang lebih dua bulan. Setelah instrumen untuk Alat Prediksi Curah Hujan disiapkan, langkah selanjutnya dilakukan pertemuan dengan Lurah Kelurahan Wonokoyo serta pihak BPBD, pertemuan dengan Kepala Kelompok Tani Ainul Hayat, serta survei ke lokasi pemasangan alat.

Setelah survei dilakukan dan didapatkan izin untuk pemasangan Alat Prediksi Curah Hujan, langkah selanjutnya adalah melakukan pembuatan alat yang terdiri dari proses pengolahan data menjadi dataset, pemodelan arsitektur sensor pengukur cuaca dan curah hujan, pembuatan Alat Prediksi Curah Hujan meliputi sensor dalam bentuk hardware dan software untuk prediksi dan melihat hasil prediksi. Proses perakitan Alat Prediksi Curah Hujan dilakukan oleh programmer dan teknisi yang ditunjuk. Proses perakitan alat tersebut dapat dilihat lebih jelas pada Gambar 5.

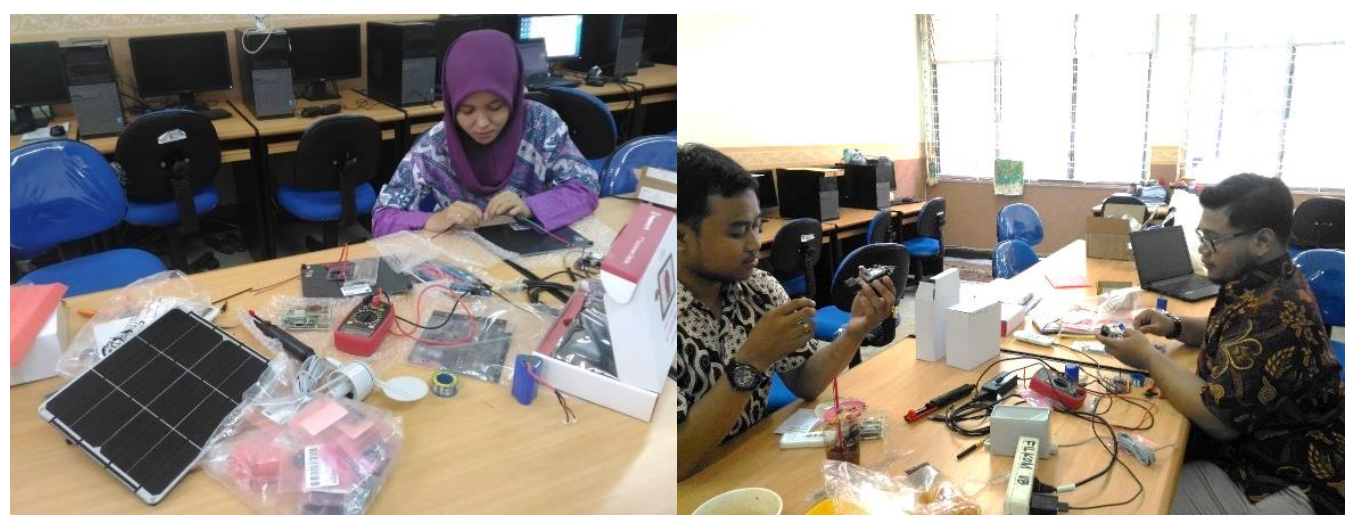

Gambar 5. Proses Perakitan Alat Prediksi Curah Hujan dilakukan oleh Pelaksana PKM, Programmer dan Teknisi

Hardware yang digunakan meliputi sensor cuaca yang disebut Stasiun Cuaca yaitu merupakan alat yang memiliki sensor-sensor untuk mengukur cuaca, seperti kecepatan dan arah angin, curah hujan, kelembaban, suhu, dan tekanan udara. Hasil pembacaan sensor akan dikirimkan ke server menggunakan koneksi internet yang terpasang pada Stasiun Cuaca. Penampakan stasiun cuaca akan dipasang dapat dilihat pada Gambar 6.

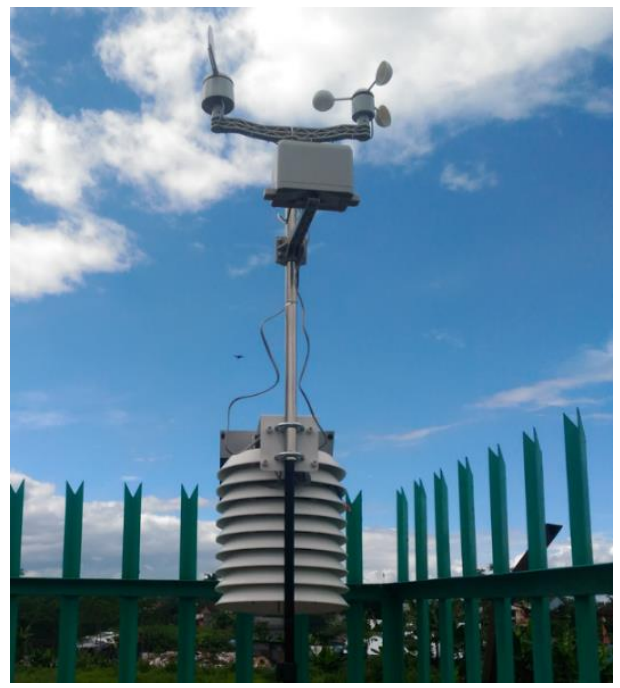

Gambar 6. Foto Stasiun Cuaca

\section{Pemasangan Alat Sensor Cuaca}


Proses pemasangan Sensor Cuaca membutuhkan beberapa tahapan. Dalam pemasangan awal ataupun saat setelah selesai perawatan, perlu untuk melakukan pemasangan rangkaian hingga alat dapat berkerja. Langkah-langkah memasang alat yaitu:

1. Sambungkan pin male RJ11 Pengukur Curah Hujan ke konektor female RJ11 yang ada di Main Board, tampilan RJ11 dapatdilihatpadaGambar 7.

2. Sambungkan pin RJ11 Pengukur Arah Angin Male ke konektor RJ11 Female yang ada di Pengukur Kecepatan Angin.

3. Sambungkan pin RJ 11 Pengukur Kecepatan Angin Male ke konektor RJ11 Female yang ada di Main Board.

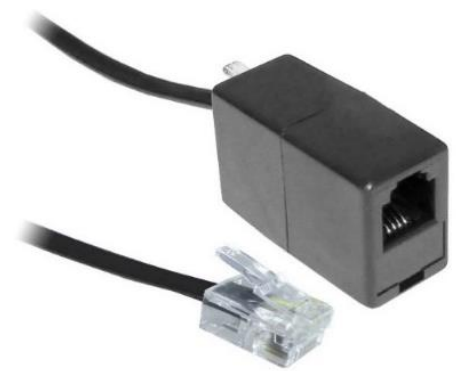

Gambar 7. Bentuk RJ11 male (kiri) dan RJ11 female (kanan)

4. Masukkkan SIM CARD 3G/4G ke dalam Modul GSM Fona bagian belakang (bentuk Modul GSM Fona dapat dilihat pada Gambar 8.
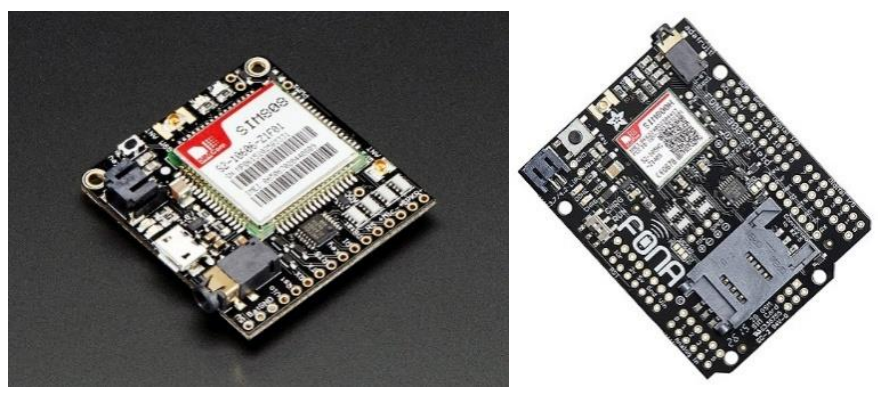

Gambar 8.Modul GSM Fona (Tampakdepandanbelakang)

5. Pasang Antenna GSM ke Modul GSM Fona.

6. Pasang Antenna GPS keModul GSM Fona.

7. Sambungkan pin JST baterai ke mainboard (bentuk pin JST dapat dilihat pada Gambar 9.

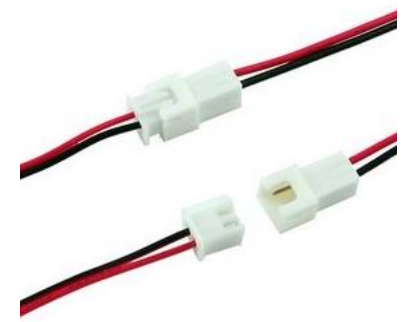

Gambar 9. Penyambungan pin JST

8. Sambungkan pin JST baterai keModul GSM Fona.

9. Sambungkan pin JST Solar panel ke mainboard.

10. Tunggu hingga lampu indikator mainboard danModul GSM Fona berkedip. 
Setelah semua komponen terpasang, maka Sensor Cuaca sudah dapat dipasang pada lokasi yang ditentukan. Pada kegiatan ini, Sensor Cuaca akan dipasang di tandon air setinggi kurang lebih 12 meter. Lokasi tandon tersebut berada pada KelurahanWonokoyo RW 5. Pemasangan alat ke atas tandon dilakukan oleh tukang dengan menggunakan paku, tiang penyangga, dan pengait. Detail dari proses pemasangan dapat dilihat pada Gambar 10.

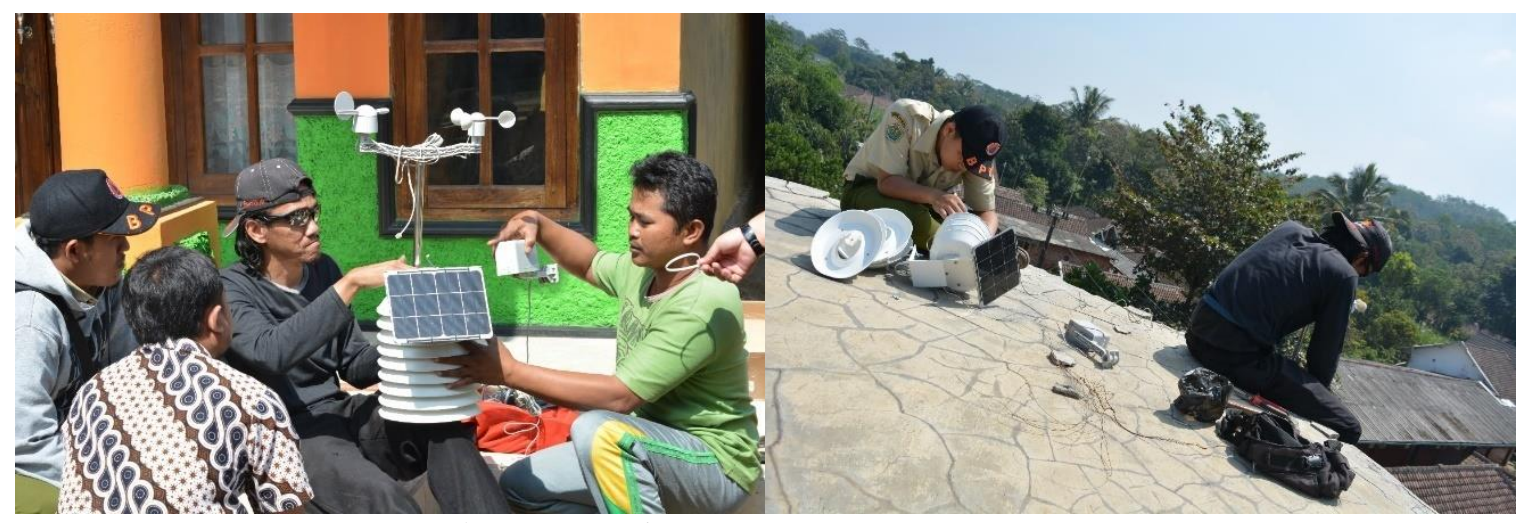

Gambar 10. Persiapan Pemasangan Sensor Cuaca

Sensor cuaca dipasang pada ketinggian sekitar 15 meter dari permukaan tanah. Gambar 11

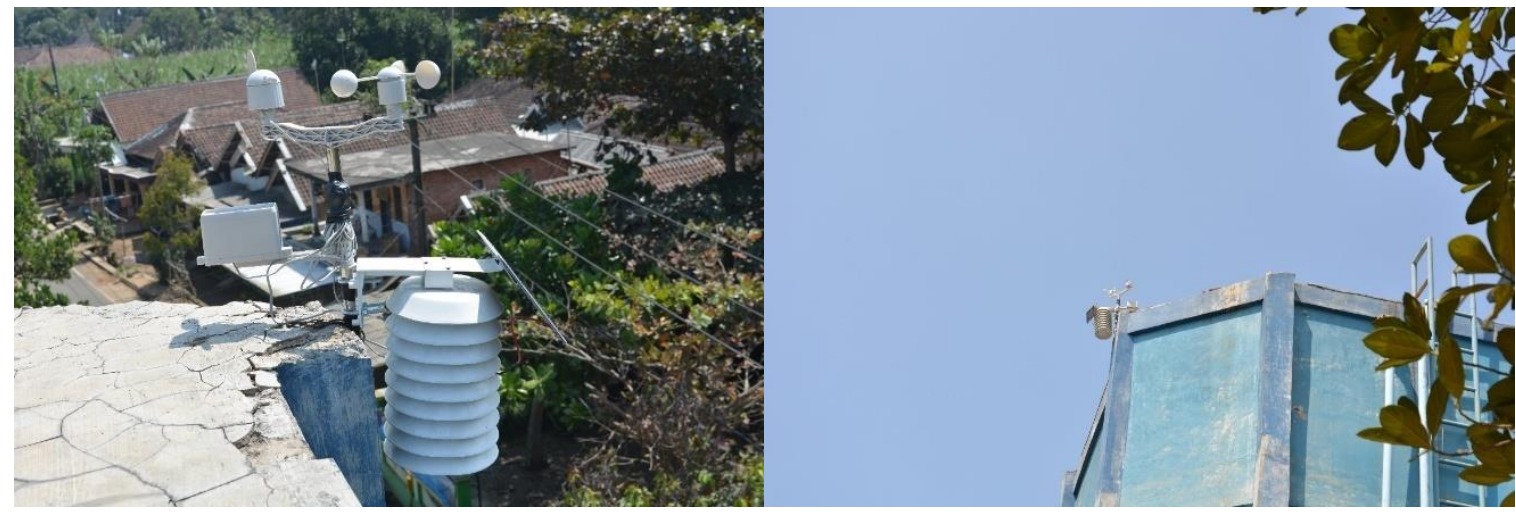

Gambar 11. Sensor Cuaca Sudah Terpasang diatas Tandon

\section{Sosialisasi Tahap 1: BPBD Kota Malang}

Software APCH merupakan perangkat lunak atau program yang berfungsi untuk memprediksi curah hujan satu hari mendatang dan memprediksi rata-rata curah hujan hingga 10 hari mendatang (satu dasarian). Software APCH membutuhkan data dari server yang selalu update. Server APCH mendapatkan data dari pusat sensor cuaca / stasiun cuaca yang dipasang di lokasi tertentu. Program ini dibuat sesederhana mungkin untuk memudahkan penggunaan. Tampilan program APCH dapat dilihat pada Gambar 12. Alur penggunaan program secara singkat adalah sebagai berikut:

1. Pilih lokasi yang diinginkan pada dropdown Pilih Data Lokasi

2. Tekan tombol Prediksi

3. Tekan tombol Lihat Hasil Prediksi di Web (opsional) 


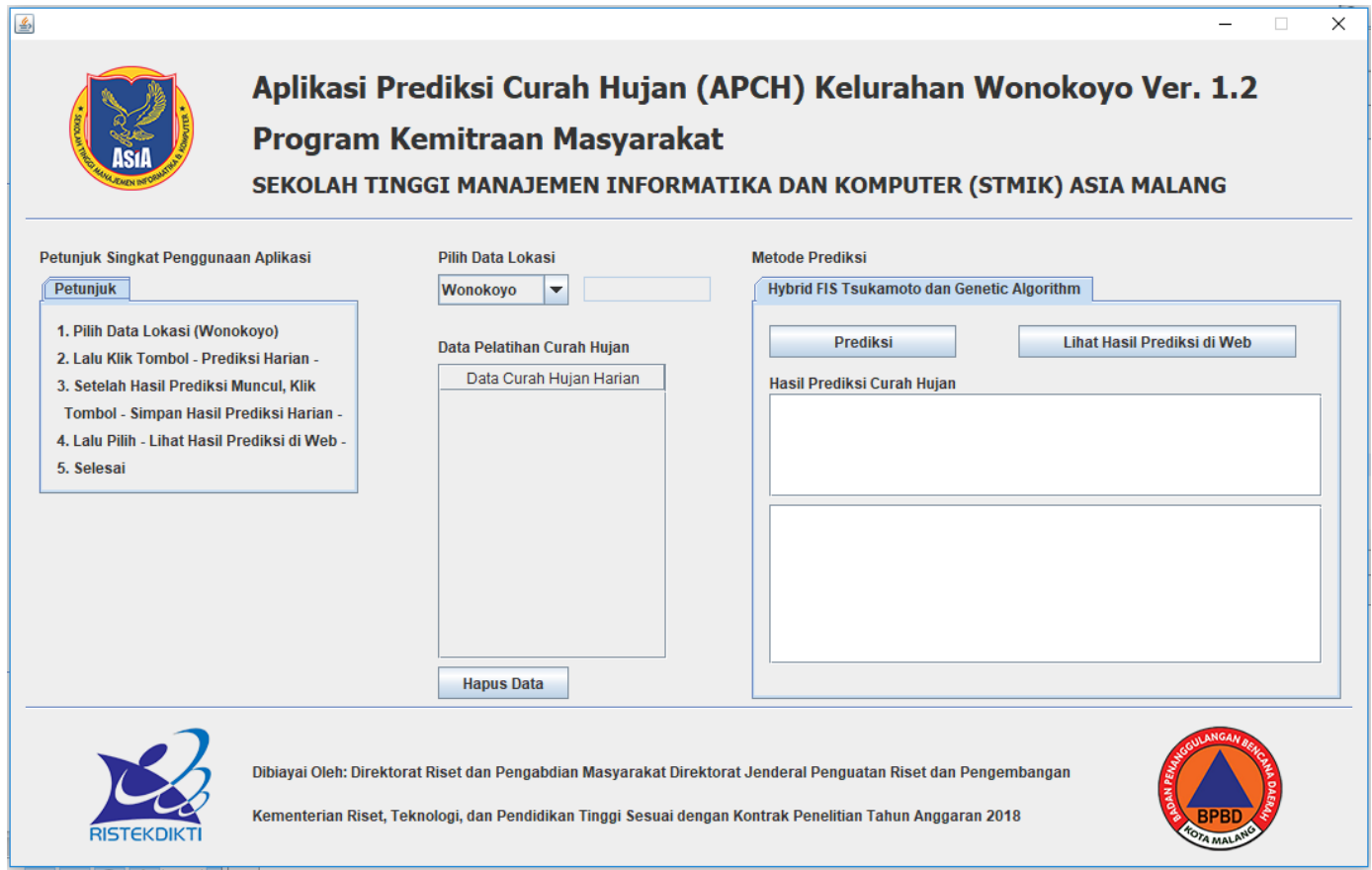

Gambar 12. Tampilan Program APCH

Hasil prediksi curah hujan dapat dilihat pada website dengan URL http://apchwonokoyo.risdian.com. Website tersebut hanya dapat diakses oleh administrator dengan memasukkan user name dan password terlebih dahulu. Tampilan salah satu halaman dari laman http://apchwonokoyo.risdian.com dapat dilihat pada Gambar 13.

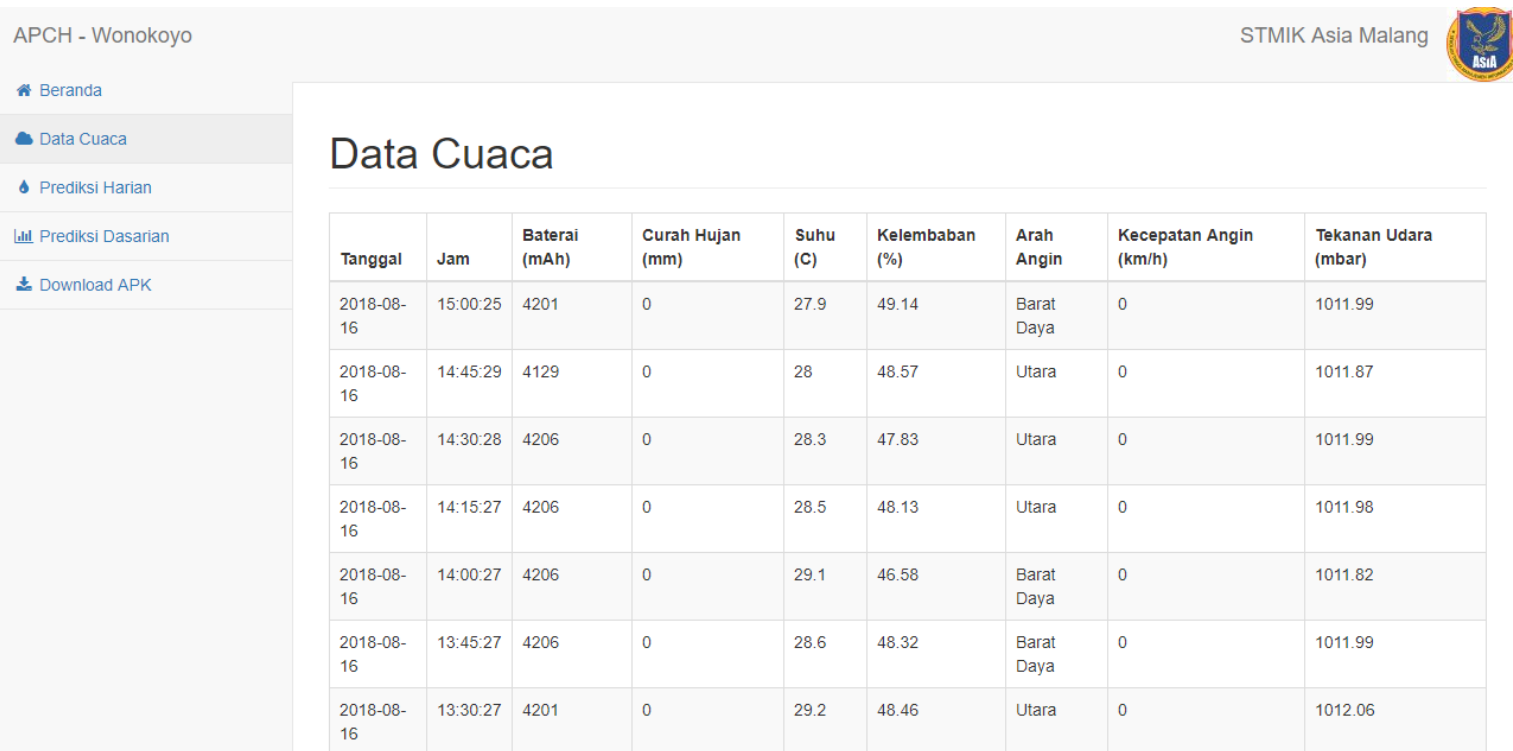

Gambar 13. Tampilan Halaman Menu Data Cuaca

Pada website tersebut terdapat tiga menu yaitu Data Cuaca, Prediksi Harian, dan Prediksi Dasarian. Menu Data Cuaca digunakan untuk menampilkan data hasil pengukuran dari stasiun cuaca berupa tanggal, jam, tegangan baterai, arah angin kecepatan angin, curah hujan, suhu, kelembaban, dan tekanan udara. Data yang ditampilkan adalah data pengukuran harian. Menu Prediksi Harian berfungsi untuk menampilkan data hasil prediksi curah hujan harian. Pada menu ini ditampilkan tanggal dan hasil prediksi curah hujan harian. Menu Prediksi Dasarian digunakan 
untuk menampilkan data hasil prediksi curah hujan selama 10 harikedepan. Pada menu ini ditampilkan tanggal mulai, tanggal berakhir, dan prediksi curah hujan dasarian.

Selain dapat dilihat pada website, hasil prediksi curah hujan juga dapat dilihat pada smartphone Android. Aplikasi yang dapat dipasang pada smartphone Android dapat diunduh pada menu Download APK. Tampilan Menu Prediksi Dasarian dapat dilihat pada Gambar 14. Agar hasil dapat dilihat pada smartphone Android ada beberapa langkah yang bisa dilakukan, yaitu:

1. Unduh file instalasi untuksmartphone Android (.apk) pada Menu Download APK

2. Pasang pada smartphone Android

3. Jalankan aplikasi tersebut

4. Tampilan pada aplikasi hampir sama dengan tampilan pada website dengan menu yang sama.

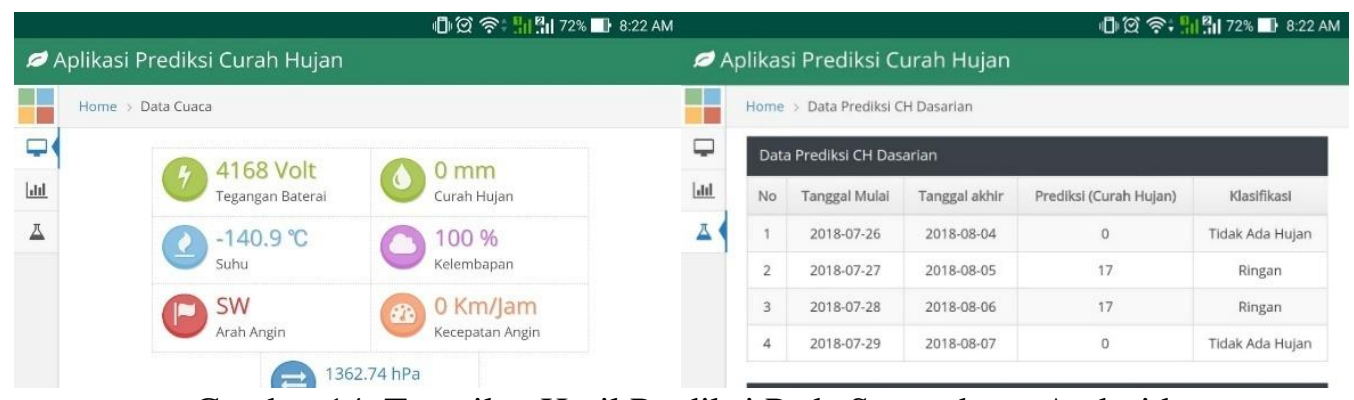

Gambar 14. Tampilan Hasil Prediksi Pada Smartphone Android

\section{Sosialisasi Tahap 2: Kelompok Tani dan Warga Kelurahan}

Sosialisasi yang dilakukan kepada Kelompok Tani danWargaKelurahanWonokoyo Kota Malang hampir sama dengan materisosisalisasi kepada BPBD meliputi pengenalan program, pengenalan cara membaca hasil prediksi melalui website dan smartphone Android, pengenalan Stasiun Cuaca dan cara maintenance Stasiun Cuaca, serta tambahan materi tentang cara pembacaan hasil prediksi curah hujan. Selain tambahan tersebut, diberikan juga edukasi tentang hubungan curah hujan dengan proses penanaman tebu, palawija, dan sayur-sayuran. Selain edukasi, juga diberikan modul sebagai bahan bacaan dan acuan yang dapat digunakan para petani dalam meningkatkan pengetahuan bertani mereka.

Pembacaan hasil pengukuran dan prediksi curah hujan akan menentukan beberapa hal, yaitu banyaknya curah hujan yang turun, serta penentuan awal musim kemarau dan musim hujan. Untuk membaca hasil curah hujan yang diukur dan diprediksi adalah sebagai berikut:

1. Curah Hujan (mm): Merupakan ketinggian air hujan yang terkumpul dalam tempat yang datar, tidak menguap, tidark meresap, dan tidak mengalir.

Curah hujan $1 \mathrm{~mm}$ (milimeter) = dalam luasan satu meter persegi pada tempat yang datar tertampung air setinggi satu milimeter atau tertampung air sebanyak 1 liter.

Sebagai Ilustrasi:

Curah hujan $10 \mathrm{~mm}$ pada luasan $1 \mathrm{~m}^{2}=10$ liter air

Curah hujan $100 \mathrm{~mm}$ pada luasan $1 \mathrm{~m}^{2}=100$ liter air

\section{Klasifikasi Curah Hujan}

Klasifikasi curah hujan menurut Badan Meteorologi, Klimatologi, dan Geofisika (BMKG) (BMKG, 2018) ditunjukkan pada Tabel 1.

Tabel 1. Klasifikasi curah hujan menurut BMKG

\begin{tabular}{lll}
\hline \hline No. & Klasifikasi & Rentang Nilai \\
\hline 1 & Sangat Ringan & $<5 \mathrm{~mm} /$ hari \\
2 & Ringan & $5-20 \mathrm{~mm} /$ hari \\
3 & Sedang & $21-50 \mathrm{~mm} /$ hari \\
4 & Lebat & $51-100 \mathrm{~mm} /$ hari \\
5 & Sangat Lebat & $>100 \mathrm{~mm} /$ hari \\
\hline \hline
\end{tabular}


*Jika terjadi hujan sangat lebat (lebih dari 100 mm/hari) maka perlu waspada terhadap banjir.

Penentuan awal musim kemarau dimulai jika jumlah curah hujan dalam 10 hari (1 dasarian) kurangdari $50 \mathrm{~mm}$ dan diikuti oleh 20 hari (2 dasarian) berikutnya. Berdasarkan data tahun 19812010, permulaan musim kemarau dapat maju atau mundur dari normalnya. Menurut BMKG awal musim kemarau pada daerah Malang antaradasarian I - III Mei 2018. Lebih detail data prakiraan awal musim kemarau pada Tahun 2018 dapatdilihatpadaTabel 2. Sedangkan penentuan awal musim kemarau dimulai jika jumlah curah hujan dalam 10 hari (1 dasarian) samaataulebih dari 50 mm dan diikuti oleh 20 hari ( 2 dasarian) berikutnya. Berdasarkan data tahun 1981-2010, permulaan musim kemarau dapat maju atau mundur dari normalnya.

Tabel 2. Perkiraan Awal Musim Kemarau di Malang, Jawa Timur

\begin{tabular}{ll}
\hline \hline Daerah & AwalMusinKemarauDasarian \\
\hline Malang bagian selatan & Mei I - Mei III \\
Blitar bagian timur laut, Malang bagian tengah & Mei II - Jun I \\
Kota Malang, Malang bagian timur dan tenggara & Mei I - Mei III \\
Trenggalek bagian timur, Tulungagung bagian selatan, & Apr III - Mei II \\
Blitar bagian selatan, Malang bagian barat daya & \\
\hline \hline
\end{tabular}

\section{Hasil Sosialisasi Alat Prediksi Curah Hujan}

Dengan adanya sosialisasi yang dilakukan pada BPBD Kota Malang. Kelompok Tani dan Warga Kelurahan Wonokoyo membuat petugas dan masyarakat menjadi mengerti cara penggunaan, perawatan, serta pembacaan hasil prediksi curah hujan. Antusias para petugas di BPBD dan warga Kelurahan Wonokoyo sangat baik dan bersemangat. Mereka merasa terbantu untuk mengetahui data cuaca dan terbantu dalam memprediksi curah hujan ke depan. Dokumentasi dari kegiatan sosialisasi di BPBD Kota Malang dapat dilihat pada Gambar 15.

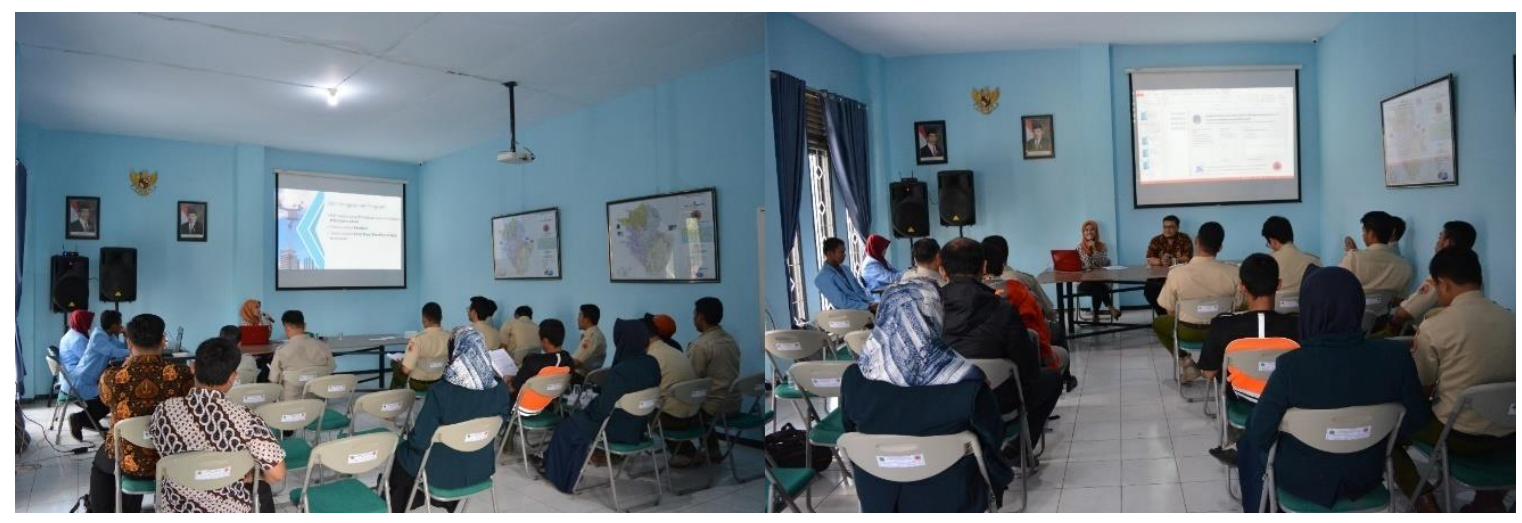

Gambar 15. Sosialisasi di BPBD Kota Malang

Pada Gambar 15 ditunjukkan proses sosialisasi dengan anggota BPBD yang berlokasi di Ruang Rapat Kantor BPBD Kota Malang. Acara sosialisasi dimulai pukul 09.00 sampai pukul 12.00. dalam sosialisasi tersebut disampaikan materi tentang cara penggunaan software APCH, penjelasan mengenai cara pengoperasian stasiun cuaca, cara maintenance stasiun cuaca. Sosialisasi di BPBD Kota Malang juga didatangi oleh programmer yang membantu membuat APCH. Dalam sosialisasi tersebut programmer menyampaikan hal-hal teknis yang berhubungan dengan stasiun cuaca. Antusiasme peserta workshop cukup baik dengan banyaknya pertanyaan yang diajukan. Perwakilan peserta sosialisasi dari BPBD Kota Malang ditunjukkan pada Gambar 16. 


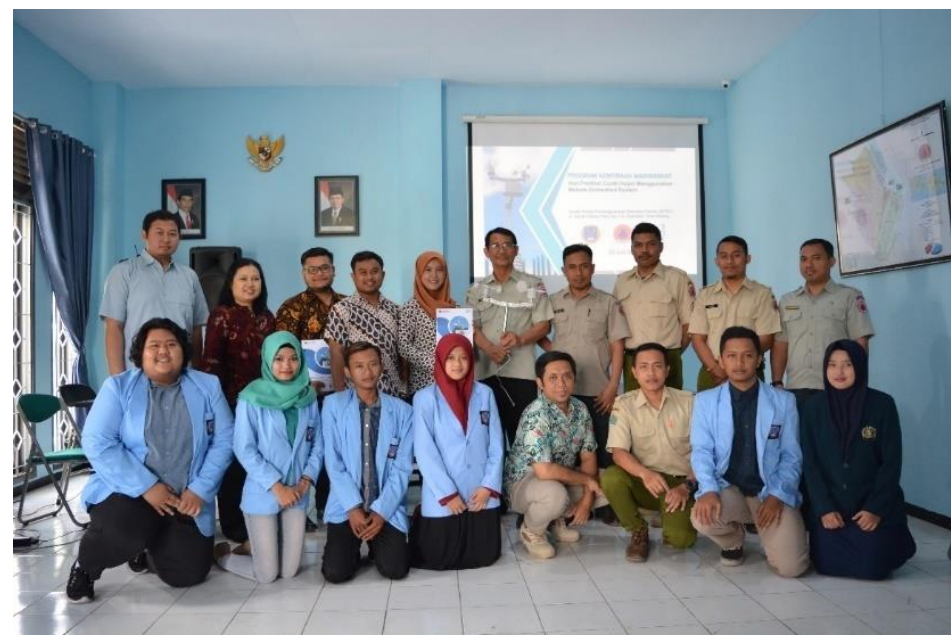

Gambar 16. Peserta Sosialisasi di BPBD Kota Malang

Kegiatan sosialisasi APCH kedua berada di KelurahanWonokoyo yang dilaksanakan di SDN Wonokoyo 2 yang lokasi nya tidak jauh dari lokasi pemasangan stasiun cuaca. Perwakilan peserta yang diundang pada sosialisasi tersebut adalah dari perangkat desa termasuk Sekretaris Lurah, Ketua RW 1, RW 2, RW 3, dan RW 5, serta perwakilan dari kelompok tani dan warga Kelurahan Wonokoyo. Selain mendapat materi penggunaan dan pembacaan hasil $\mathrm{APCH}$, para peserta juga mendapatkan buku yang berisi pedoman menanam tebu dan palawija (jagung, cabai, dan sayursayuran). Diharapkan para petani yang tergabung dalam Kelompok Tani Ainul Hayat dapat membagikan ilmu yang didapatkan dari sosialisasi dan buku pedoman kepada petani-petani lain di Kelurahan Wonokoyo. Selain proses sosialisasi, juga dilakukan penandatanganan serah terima APCH dan Stasiun Cuaca kepada perwakilan dari KelurahanWonokoyo dan BPBD Kota Malang. Dalam surat serah terima tersebut tertulis bahwa software dan alat sudah resmi dihibahkan kepada Kelurahan Wonokoyo dan BPBD Kota Malang. Pada Gambar 17 ditunjukkan beberapa perwakilan dari peserta sosialisasi APCH di kelurahan Wonokoyo.

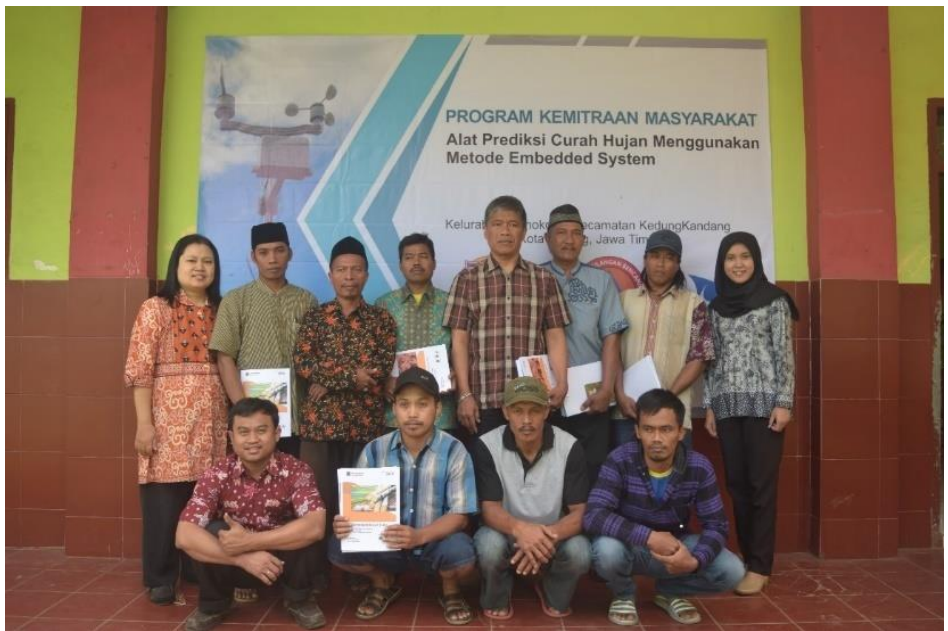

Gambar 17. Sosialisasi di KelurahanWonokoyo, Kota Malang

\section{KESIMPULAN}

Alat Prediksi Curah Hujan (APCH) yang dibuat dengan kombinasi sensor cuaca dan algoritma hybrid FIS-GA telah dibuat dan diimplementasikan di KelurahanWonokoyo RW 5. Hasil yang diberikan dari APCH adalah tampilan data cuaca hari ini antara lain curah hujan, suhu, kelembaban, tekanan udara, arah angin, dan kecepatan angin. Selain itu, APCH juga dapat digunakan untuk memprediksi curah hujan di daerah Kelurahan Wonokoyo untuk satu hari ke 
depan dan rata-rata curah hujan untuk sepuluh hari ke depan. Data cuaca dan data hasil prediksi dari APCH akan digunakan untuk membantu petani dalam memperkirakan masa tanam dan masa pemupukan. Dengan begitu, petani tidak perlu lagi memperkirakan kondisi cuaca dan kondisi hujan selama melakukan proses pertanian. Kedepannya akan dilakukan pengawasan dan evaluasi secara bertahap dalam kurun waktu beberapa tahun untuk mengetahui dampak penggunaan APCH secara langsung.

\section{UCAPAN TERIMAKASIH}

Program Kemitraan Masyarakat (PKM) ini secara financial didanai oleh Kementerian Riset, Teknologi, dan Pendidikan Tinggi (Kemenristekdikti) melalui program hibah Penelitian Dosen Pemula (PDP), Badan Penanggulangan Bencana Daerah (BPBD) Kota Malang, dan Badan Meteorologi, Klimatologi, dan Geofisika Karangploso, Malang.

\section{DAFTAR PUSTAKA}

Ardianto, Y. T. (2009). Analisis harga pasok, kualitas layanan dan kemudahan terhadap loyalitas petani tebu gondanglegi kabupaten malang. Fakultas Ekonomi Universitas Merdeka Malang, $1-16$.

Asriasuri, H. (1998). KEBUTUHAN AIR TANAMAN TEBU DAN HUBUNGANNYA DENGAN CARA PEMBERIAN AIR SECARA CURAH DAN TETES (Water Requirement of Sugarcane and Its Relation Witll tile Sprinkle and Drip Irrigation System). BULETIN KETEKNIKAN PERTANIAN, 12(1), 1-11.

BMKG. (2018). Prakiraan Musim Kemarau 2018 di Indonesia.

Wahyuni, I., \& Mahmudy, W. F. (2017). Rainfall Prediction in Tengger-Indonesia Using Hybrid Tsukamoto FIS and Genetic Algorithm. Journal of ICT Research and Applications, 11(1), 38-54. https://doi.org/10.5614/itbj.ict.res.appl.2017.11.1.3

Wahyuni, I., Mahmudy, W. F., \& Iryani, A. (2016). Rainfall Prediction in Tengger Region Indonesia Using Tsukamoto Fuzzy Inference System. 1st International Conference on Information Technology, Information Systems and Electrical Engineering, ICITISEE 2016, 16, 130-135. https://doi.org/10.1109/ICITISEE.2016.7803061

Wahyuni, I., Wibowo, F. L., Rahman, F., Mahmudy, W. F., \& Iriany, A. (2017). Design and Implementation of Automatic Weather Station using MQTT Protocol. International Journal of Tomography \& Simulation (In Press), x(x), 1-8. https://doi.org/10.22266/ijies2016.xxxx.xx 